\title{
Innovation and technology uptake on farm
}

\author{
W. J. LISSAMAN ${ }^{1}$, M. CASEY ${ }^{2}$ and J.S. ROWARTH ${ }^{3}$ \\ ${ }^{1}$ Breach Oak, RD Seddon, Blenheim, New Zealand \\ ${ }^{2}$ PGGWrightson Ltd, Private Bag1961, Dunedin, New Zealand \\ ${ }^{3}$ Waikato Management School, The University of Waikato, Private Bag 3105, Hamilton 3240, New Zealand \\ w.lissaman@nettel.net.nz
}

\begin{abstract}
The belief that the average farmer in New Zealand is too old to adopt new technologies overlooks the evidence, and the overseas literature aligning adoption with education experience and financial security. It also overlooks the fact that many innovations are developed on farm by people experienced in what they are doing. This paper reviews the literature from a wide source of perspectives synthesising information and allowing examination of critical success factors (e.g., age, education, financial background, experience). New Zealand examples of innovation on farm are described. The research suggests that farmers adopt technologies when they can see the outcome in terms of the bottom line for their farming system. Education, experience and financial security are all part of the mix that allows the benefits to be evaluated against the risks. These farmers have the background to adapt new technologies to their farming systems, and to develop innovative approaches to meet new production challenges, whether environmental, economic or regulatory.
\end{abstract}

Key words: Adoption, adaptation, end-user, extension

\section{Background}

Improving farm management skills across all New Zealand farmers to match those of the top farmers would achieve productivity gains; the gains would be from technologies (practices and new equipment) that already exist (Ministry for Primary Industries 2013). In the dairy sector, for instance, the most profitable $10 \%$ of farmers achieve almost $\$ 2000$ per hectare profit before tax more than the average (\$4105 cf. \$2159) after servicing a similar amount of debt (\$1256 cf. \$1253) (Ministry for Primary Industries 2012).

For the New Zealand economy, overcoming the profit gap, whilst operating within increasing environmental constraints, is vital. Extension and advisory services are considered to be critical to facilitate farmers' access to technology and knowledge (OECD 2012), and government funding for extension services has increased in the countries in which it exists. In the USA, over $60 \%$ of funding for extension comes from Government; in Iceland the share changed from $25 \%$ in $1995-97$ to $80 \%$ in 2009-2011. The European Union was less than $10 \%$ in $1995-1997$ but had doubled by 2009-2011. New Zealand has no government-funded extension service. It does, however, have levy-bodies paid for by farmer production, and the levy bodies do have consulting officers and extension officers operating in various ways to assist farmers.

A TNS (a global communications services company) survey (Mustard \& McKibbin 2012) of 450 New Zealand farmers and their farming information sources reported farming newspapers as the most common sources $(73 \%)$, with magazines next most common (39\%) followed by the internet (32\%). Neighbours, friends, family and other farmers were rated by only a quarter of farmers, and consultants by only $14 \%$. Farm discussion groups were used by $14 \%$ and field days were attended by $6 \%$ of respondents. However, when asked to rate the value of information from different sources, sheep farmers ranked the media as only average, while scientists, monitor farms, discussion groups and veterinarians were highly ranked (Stevens et $a l$. in press). The Ministry of Primary Industries (2013) survey supports the low engagement with consultants, which probably reflects the lack of a governmentfunded extension service in New Zealand and the fact that, although most farmers would be prepared to pay $\$ 1500$ a year for advice (James Allen, pers. comm. April 2013), professionals value their time more highly; one-on-one advice costs more than farmers are prepared to pay.

The result is an oft-repeated statement that current farmers are set in their ways and that a step change in technology uptake will not occur until the next generation of farmers enters farm ownership. This overlooks the fact that farmers are sourcing the information they think they need (through newspapers, etc.). It also overlooks the literature that suggests current farmers may be making decisions that exactly suit their environment (discussed throughout subsequent sections and supported by the productivity statistics).

\section{Technology Transfer}

Human capital has been identified as the most important factor in technology transfer (Rogers 1995). A meta-analysis of over 500 technology uptake studies 
conducted during the 1960s enabled categorisation of technology transfer according to five types of people:

1. Innovators are the first adopters. They are willing to take risks, youngest in age, have the highest social class (which in the 1960s is likely to equate to confidence), have great financial liquidity, are very social (now termed networked) and have close contact to scientific sources and other innovators.

2. Early adopters are the second fastest to apply new technologies and are regarded as leaders by people in other categories. In New Zealand they might be the people involved in monitor farms and industry boards. Like innovators, in the 1960s these were typically younger in age, with higher social status, were financially stable, had advanced education and are more conservative in adoption choices than innovators - perhaps afraid of losing face in the eyes of their peers and wanting to maintain their central position in networks.

3. The early majority tend to be slower in adoption, but have contact with early adopters.

4. The late majority tend not to be financially stable and aren't as well connected as the other categories.

5. Laggards are the last to adopt new technologies and are typically "advanced in age". They have the lowest financial viability and are poor at networking. Laggards or resistors may be an important sector to focus on for farmer adoption as a proportion are likely to leapfrog technology (e.g. they move to smartphones despite not having used a computer) (Goldenberg \& Oreg 2007).

Research on innovation from the Netherlands (Diederen et al. 2003) involving over 1000 farmers also reported that younger farmers are more likely than older farmers to adopt innovation; this effect was linked with education rather than age per se. Of relevance for New Zealand are the findings that farms with larger businesses (spreading fixed costs for innovation) and more solvency (to pay for it) are more likely to take the risk of adoption. This suggests that it might be the older farmers that are in the best position to adopt new technologies successfully because they know their business and so are likely to pick new technologies appropriately, hence increasing productivity.

Data from the Kauffman Foundation supports the suggestion that maturity is a strong foundation for innovation. It indicates that the highest rate of entrepreneurship in America is in the 55-64 year age group, with people older than 55 almost twice as likely to create successful companies as people in the 20-34 year age group (Theil 2010).
Any concept that farmers are too old to change, and the new technologies will come in with the new recruits, isn't supported by the literature, or the data on productivity.

\section{Productivity}

Statistics New Zealand's report on Industry Productivity Statistics: 1978-2011 released in April showed that agriculture contributed strongly during the period (Statistics New Zealand 2013a). Labour productivity increased $3.4 \%$ per annum in agriculture. Capital productivity (the ratio of output to capital input) also increased by $2.2 \%$ per annum.

For multi-factorial productivity (the ratio of output to total inputs, and reflecting growth that cannot be attributed to capital or labour, such as technological change or improvement in knowledge, methods and processes) agriculture increased $2.8 \%$ annually. These data indicate that farmers are adopting and adapting new technologies enabling increased efficiencies and increased output per input on farm. Similarly, DairyNZ (2007) estimates that between 1998/99 and 2005/06, the value of productivity gains in the dairy industry was $\$ 1.17$ billion.

Constraints to productivity growth have been identified (Fuglie 2012) as "primarily research capacity, with a binding constraint in extension/education capacity". Once a threshold capacity in extension/ education was achieved, research capacity was the factor distinguishing low and high productivity growth countries. In New Zealand the education status is above average according to the OECD figures, but extension and research are underfunded.

Meta-analysis of 292 publications on the benefits of R\&D in agriculture, involving 1886 observations (Alston 2010), suggests that the world has systematically underinvested in agricultural R\&D and is probably continuing to do so. The overall problem with R\&D investment, in the laboratory and on farm, is the difficulty of proving it results in economic benefits because of the long lag phase, even though the benefits then last a long time (Alston 2010). For the period 1949-2002, Alston et al. (2010) estimated that research lags had an overall length of 50 years with a peak impact at 24 years and most of the impact gone in 40 years.

Also of interest is that over the years, the proportion spent on food processing and product development has increased from $49 \%$ to $54 \%$, with a consequent decrease in funding for research focussed on improving inputs used (Beintema et al. 2012).

In New Zealand there have been many concerns raised about research funding, research direction and research results. The Grassland Association Presidents have been vocal about such issues as scientific argument and 
sorting fact from fiction (Caradus 2008), the increase in papers based on surveys and models rather than data from experiments and trials (Crofoot 2011), and the research system in general (Rowarth 2012). Basic research and proof of concept based on understanding of "plant science first principles or fundamentals" needs to pre-date the sale of new technology, and a need has to be identified (Parsons et al. 2011a,b).

\section{Adoption and diffusion}

A NIDEA working paper (Jackson 2013) based on the latest population census reported that $36.5 \%$ of grain, sheep and cattle farmers are now $55+$ years, in contrast to $30.4 \%$ in 2001 and $25.1 \%$ in 1996 . At the same time the general New Zealand population has also aged (Statistics New Zealand 2013b). When corrected for the same proportional increase from an aging population, the proportion of farmers $55+$ should have increased to $33.4 \%$, suggesting that most of the "aging" of farmers is a reflection of general population dynamics. Constant reminders of "the average age of farmers" has increased the pressure to plan for succession. This is despite the fact that it is the mature farmers that have the experience to test new ideas and technologies to see if they have some real advantage on farm. Experienced and successful farmers have spent many years fine tuning their systems to use the resources they have to optimise potential and fit their system to the biology of the plants grown. Having done the fine tuning they can work to maximise the potential of the system by incorporating different plant species into the system design, or changing the animal species or class to optimise plant potential. Examples of changes in practice include implementation of pregnancy scanning; changed weaning management; body condition scoring; improved lamb survival, and the feeding of triplet- and quad-bearing ewes pre-lambing to enhance survival. The increased use of lucerne grazing systems, epitomised by Doug Avery (Avery et al. 2008), and further developed by the Sustainable Farming Fund Lucerne for Lambs project working with farmers to model a lucerne grazing system for Central Otago in Central Otago (Stevens et al. 2012), are examples of a farming system changing to improve the match with climate and allowing increased productivity.

Another example of changes to increase productivity is the move from all grass farming to supplementary feeding in dairy. There are now considered to be five types of production systems, based on the time of year that imported feed is used (Hedley et al. 2006; DairyNZ 2012). The overall effect of technology and feeding has allowed more cows to be managed per hectare and per person. DairyNZ (2012) Economic Survey results indicate that in a year of high pay out, system 4 and 5 farmers (high imported feed) account for $30 \%$ of top performing farms, although together they represent only $19 \%$ of owner-operated farms. In contrast, system 1 farms (all grass) formed $11 \%$ of the farms in the survey and accounted for $19 \%$ of the farms in the bottom quartile for operating profit.

In Marlborough, many farmers have already implemented both mitigation and adaptation practices to "manage for change". Research (Niles et al. 2013) is elucidating the impact for the economy if, for instance, stocking rate is decreased to increase resilience for drought. At the same time, farmers have shown a strong interest in new types of crops and forages. This is important for industry and academic research, and for policy. Policymakers can use the research to understand the potential economic and environmental shifts that may occur as a result of change in practice to develop appropriate policy strategies for optimising the adoption of climate mitigation and adaptation strategies (Niles et al. 2013).

A recent initiative of the meat companies is to take experienced and respected suppliers, who have the storyline to demonstrate their attachment to the product and brand values, on market tours. These people, who model the family farm, are the ones to drive the change, and carry their vision into the next generation's endeavours. The hope is that the initiative adds value to the industry as well as encouraging technology adoption on farm.

Uptake of innovation depends upon five factors (Robinson 2009): (1) relative advantage, (2) compatibility with existing values and practices, (3) simplicity and ease of use, (4) trial-ability, and (5) observable results.

Within relative advantage (the first of the five), personal control, time saving and self-esteem are thought to be of most importance (Robinson 2009), but economic factors, convenience, prestige and satisfaction are also considered.

Compatibility reduces inertia in adoption incompatibility means that adoption is unlikely until the relative advantages increase. This is exemplified in the "rock bottom moment for change". In New Zealand there are increasing numbers of stories of change (e.g., Avery et al. 2008; Reynolds 2013) following a major event such as drought involving "rock bottom" descriptions.

Simplicity and ease of use reduces the need for assistance in adoption, and result in rapid uptake of a technology (e.g., Stevens et al. 2011). Similarly, trialability and observable results increase confidence in adoption; professionals can assist and so increase confidence. These five qualities determine between $49 \%$ and $87 \%$ of the variations in adoption of new 
technologies (Rogers 1995).

A considerable number of reports on the general topic of technology transfer and innovation adoption have been released after Nuffield and Kellogg studies in New Zealand in the last few years.

Waugh (2011) examined European attempts to address the issue of water quality and the impact of agriculture and whether incentives or regulation was most effective. Recommendations were many and involved partnership, collaboration, education, and a combination of incentives and regulation. On the same topic of environmental impact, a Kellogg report (van Reenen 2013), based on information from New Zealand sheep and beef farmers, also recommended collaboration and identified that farmers adopted new technologies where benefits could be seen (Robinson 2009). Further recommendations included developing a comprehensive website and establishing a Mentor Scheme using farmer Environmental Champions. Van Reenen (2013) suggested that any information transfer should be farmer focussed, practical, benefitorientated, be well supported, reward good behaviour and acknowledge that change takes time.

Fitzgerald (2012) recommended structured innovation development for farmers through such concepts as incubators and structured creative exploration groups with supported discovery within a supportive network. The cost benefit analysis for individuals was not examined.

All of these reports indicate that partnership is key to assist farmers to adopt new technologies; partnership reduces risk and Taylor (2013) suggests that supporting farmers with implementation of innovations rather than "simply leaving the manager with a set of recommendations to implement" is the key to achieving change and maximum value.

\section{The Answer}

In giving the Levy Oration last year, Past President Pat Garden reminded delegates that end-user innovation is by far more the most important and significant source of innovation. He also said that a critical components of end user innovation is " 'informal know how trading', a term coined by Eric von Hippel in his book 'Sources of Innovation'. This is essentially a pattern of informal cooperative R\&D. If we apply that to a farming context, our heritage of discussion groups, focus farms and monitor farm groups is a perfect fit" (Garden 2013). McIvor \& Aspin (2001) reported a return of more than twenty dollars per dollar of industry investment to the national monitor farms programme. The monitor farm programme was also identified as important for motivating practice change, e.g., liveweight and pasture monitoring and pregnancy scanning. In addition the farmers involved identified other benefits such as motivation and stimulus, networking with other farmers, scientists and agribusiness, confidence in decision making, business planning, goal setting and benchmarking.

Payne et al. (2009) found that farmers who regularly attended deer focus farm field days made more changes than those that only read the newsletter (4.6 compared to 2 changes per farmer) demonstrating the impact of both the focus farm model and the on-going availability of information (newsletters).

Research in Uruguay involving 14 farms and farmers, technical advisors and scientists in a coinnovation process resulted in a 50\% increase in farm income. The research combined systemic diagnosis and redesign of social systems, social learning and dynamic monitoring and evaluation. As well as improved income, on 11 of the 14 farms' environmental impact was reduced (Dogliotti et al. 2013). At the end of the 2-5 years of redesign, farmers had implemented most of the innovations planned, and identified "multi-year planning" as the most important change introduced into their practice by the project. It was suggested that the role of the extension service agents should change from being consultants of "operationaltactical, crop-centred decisions" to supporters of the process of farm planning and evaluation. The project showed that even on commercial farms in competitive conditions, considerable improvements in economic and environmental indicators were achieved when a whole farm strategic redesign was implemented.

In New Zealand, better research that shows bottom line improvements is required. A decision support or sensitivity test for identifying which changes would enable greatest improvement most easily (the bang for the buck concept) should be developed (e.g., how much $\mathrm{N}$ and $\mathrm{P}$ saved per mitigation step; McDowell \& Nash 2011). This would enable easy steps to be taken, thus encouraging greater moves. This is where systems modelling could have its greatest impact (Rendel et al. 2013), particularly if a system of rewards for efficient production per unit of N, P and C used or lost could be designed (Tillman et al. 2008).

In addition, research into better understanding of the complexity of farm system changes and their impacts is required, especially as in many cases the simple changes have been made and future changes will be increasingly disruptive.

It is also increasingly important that farm systems research is developed that includes both demonstration and discovery, where the technical extension is an integral part of the initial project plan and design. Examples of this type of project are outlined in Stevens et al. (2012) (lucerne), Stevens et al. in press b (deer 
focus farms) and Stevens et al. (2011) (4-day shifting).

The open channels of two-way communication between the scientist and the farmer enable idea exchange; the dilution and/or filtering of the message by middlemen (such as industry professionals) can create problems if they become gatekeepers for the information. However, the middlemen can develop an idea once the system has been created, enabling others to learn and adopt, and often they can enable adoption of technologies which create solutions to hiccups or hurdles to the system design (e.g., Lucerne for Lambs; Stevens et al. 2012). They can also assist the researchers to understand farm limitations or system impacts. Furthermore, with the rapid movement of technology and increased access to information the limiting factor in uptake is "knowledge" - that is, understanding the information in context. In this "middlemen" can add considerable value (Grain and Graze 2; England in press).

The answer to yet greater innovation and adoption in New Zealand is partnership across sectors and generation, and a multi-year concept. Interaction within agribusiness, from farm to fork, will strengthen the existing networks, improving the ideas and providing a foundation for advance. Diversity of experience and knowledge is urged in governance theories to improve productivity. Undoubtedly it will work within the operational part of the agribusiness sector as well. The New Zealand Grassland Association members, the exchange of information at the conferences and symposia, plus the interaction through newsletters and proceedings, epitomise the solution to the challenge of enhancing innovation and technology transfer.

\section{REFERENCES}

Alston, J.M. 2010. The benefits from agricultural research and development, innovation and productivity growth. OECD Food, Agriculture and Fisheries Papers, No. 31, OECD Publishing. www. oecd.org http://doi.org/10.1787/5km91nfsnkurg-en

Alston, J.M.; Andersen, M.A.; James, J.S.; Pardey P.G. 2010. Persistence pays: U.S. agricultural productivity growth and the benefits from public R\&D spending. Springer, New York.

Avery, D.; Avery, F.; Ogle, G.I.; Wills, B.J.; Moot, D.J. 2008. Adapting farm systems to a drier future. Proceedings of the New Zealand Grassland Association 70: 13-18.

Beintema, N.; Stads G-J.; Fuglie, K.; Heisey, P. 2012. ASTI Global assessment of agricultural R\&D spending; developing countries accelerate investment. International Food Policy Research Institute, Washington. 18p.
Caradus, J. 2008. Presidential Address: An opportunity lost and sorting fact from fiction. Proceedings of the New Zealand Grassland Association 70: 1-6.

Crofoot, A. 2011. Presidential Address: New Zealand needs more production pastoral research. Proceedings of the New Zealand Grassland Association 73: 5-8.

DairyNZ 2007. Return on farmer investment http:// www.dairynz.co.nz/page/pageid/2145856429/ Return on Farmers Investment

(Accessed 21 July 2013)

DairyNZ 2012. DairyNZ Economic Survey 20102011.60p.

Diederen, P.; Meijl van H.; Wolters, A.; Bijak, K. 2003. Innovation adoption in agriculture: innovators, early adopters and laggards. Cahiers d'Économie et Sociologie Rurales 67: 30-50.

Dogliotti, S.; Garcia, M.C.; Peluffo, S.; Dieste, J.P.; Pedemonte, A.J.; Bacigalupe, G.F; Scarlato, M.; Alliaume, F.; Alvarez, J.; Chiappe, M.; Rossing, W.A.H. 2013. Co-innovation of family farm systems: a systems approach to sustainable agriculture. Agricultural Systems http://dx.doi.org/10.1016/j. agsy.2013.02.009. (Accessed 27 April 2013)

England, D. in press. The stepped adoption of grazing crops in Western Australia. Extension Farming Systems Journal in press.

Fitzgerald, R. 2012. Understanding the drivers for creation and adoption of innovation by farmers; on and off farm. New Zealand Nuffield Farming Scholars Association Scholarship Report. 26p.

Fuglie, K.O. 2012. Productivity growth and technological capital in the global agricultural economy. In: Productivity growth in agriculture: an international perspective. Eds. Fuglie, K.O.; Wang, S.L.; Bell, V.E. CABI International ,Oxfordshire, UK.

Garden, P. 2013. Levy Oration. Proceedings of the Grassland Association 75: 11-14

Goldenberg, J.; Oreg, S. 2007. Laggards in disguise: Resistance to adopt and the leapfrogging effect. Technological Forecasting an Social Change 74: 1272-1281.

Hedley, P.; Kolver, E.; Glassey, C.; Thorrold, B.; van Bysterveldt, A.; Roche, J.; Macdonald, K. 2006. Achieving high performance from a range of farm systems. Proceedings of the 4th Dairy3 Conference, 147-168.

Jackson, N. 2013. A note on the demographic change in New Zealand's dairy farming industry: the need for a cohort perspective. National Institute of Demographic and Economic Analysis. 26pp.

McDowell, R.W.; Nash, D. 2011. A review of the costeffectiveness and suitability of mitigation strategies to prevent phosphorus loss from dairy farms in New Zealand and Australia. Journal of Environmental Quality 40: 1-14. 
McIvor, S.D.; Aspin, M.D. 2001. R\&D Success stories and principles to practice. Proceedings of the New Zealand Grassland Association 63: 23-27

Ministry for Primary Industries. 2012. Farm Monitoring 2012. National Dairy 12p www.mpi.govt.nz (Accessed 13 December 2012)

Ministry for Primary Industries. 2013. Survey of technology transfer services to farmers and growers in New Zealand 27p. www.mpi.govt.nz (Accessed 23 February 2013)

Mustard, D.; McKibbin, R. 2012. TNS Independent Rural Readership Survey. 39p. http://www.nzxagri. com/UserFiles/File/Rural_Readership_\%20Jan_12. pdf (Accessed 23 March 2013)

Niles, M.T.; Lubell, M.; Brown, M.; Dynes, R. 2013. Managing for change in Marlborough, New Zealand: Farmer Adoption of Practices. http:// environmentalpolicy.ucdavis.edu/project/climatechange-and-agriculture (Accessed 15 May 2013)

OECD 2012. Agricultural Policy Monitoring and Evaluation 2012 - OECD countries. www.oecd.org accessed 20 April 2013.

Parsons, A.J.; Edwards, G.R.E.; Chapman, D.F.; Caradus, J.R; Rasmussen, S.; Rowarth, J.S. 2011a. Past lessons and future prospects: plant breeding for yield and persistence in cool temperate pastures. Grass and Forage Science 66: 153-172.

Parsons, A.J.; Rowarth, J.S.; Rasmussen, S. 2011 b. High sugar grasses. CAB Reviews: 6, 046, 1-12.

Payne, T.A.; Stevens, D.R.; Casey, M.J. 2009. Deer focus farms - are they working? Proceedings of the New Zealand Grassland Association 71: 217-221.

Porter, M.E.; Stern, C. 2001. National innovation capacity. In: Global Competitiveness Report 2001. World Economic Forum and Harvard Business School. Pp 102-115.

Rendel, J.M. Mackay, A.D.; Manderson, A.; O'Neill, K. 2013. Optimising farm resource allocation to maximise profit using a new generation integrated whole farm planning model. Proceedings of the New Zealand Grassland Association 75: 85-90

Reynolds, W.N. 2013. Addressing on-farm management to enhance pasture productivity and persistence. Proceedings of the New Zealand Grassland Association 75: 241-244

Robinson, L. 2009. A summary of diffusion of innovations. Enabling Change. www.enablingchange. com.au (Accessed 11 April 2013)

Rogers, E.M. 1995. Diffusion of innovations. 4th ed. Free Press, New York
Rowarth, J.S. 2012. President's address 2012. Proceedings of the New Zealand Grassland Association 74: 7-10.

Statistics New Zealand 2013a. Industry Productivity Statistics 1978-2011. http://www.stats.govt.nz/ browse_for_stats/economic_indicators/productivity/ IndustryProductivityStatistics_HOTP78-11.aspx (Accessed 11 April 2013)

Statistics New Zealand 2013b. Population estimates http://www.stats.govt.nz/infoshare/SelectVariables. as px? pxID =dc $76 \mathrm{~d} 534-\mathrm{a} 05 \mathrm{e}-485 \mathrm{~b}-\mathrm{a} 310$ 636b9770ec83 (Accessed 21 August 2013)

Stevens, D.R.; Casey, M.J.; Scandrett J.S. in press a. Impacts of a winter feeding management on-farm extension programme in Southern New Zealand. Extension Farming Systems Journal in press.

Stevens, D.R.; Casey, M.J.; Scandrett, J.S.; Baxter, G.S. 2011. Winter feeding - changing labour requirements and productivity. Proceedings of the New Zealand Grassland Association 73: 51-56.

Stevens, D.R.; Payne, T.A.; Casey, M.J. In press b. Evaluating a deliberative learning framework to deliver science on deer focus farms. Extension Farming Systems Journal in press.

Stevens, D.R.; Thompson, B.R.; Carruthers, A.; Wall, A.J; Casey, M.J.; Phiskie, R.; Young, P.; Moot, D.J. 2012. Understanding the role of spring grazing of lucerne in the Central Otago environment. Proceedings of the New Zealand Grassland Association 74: 69-76.

Taylor, G. 2013. Managing change: the key to unlocking the value of innovation on farm. Primary Industry Management 17: 33-35

Theil, S. 2010. The golden age of innovation. Newsweek 27th August.

Tillman, R.W.; Yates, L.J.; Horne, D.J.; Hedley, M.J.; Hanly, J.A. 2008. Is "environmental efficiency" a useful concept in improving and regulating the environmental performance of pastoral farming systems? In: Carbon and nutrient management in agriculture. Eds L.D. Currie, L.D.; Yates, L.J. Occasional Report No. 21. Fertilizer and Lime Research Centre, Massey University, Palmerston North, New Zealand.

Van Reenen E. 2013. Increasing uptake of environmental practices on sheep and beef farms. Kellogg Rural Leaders Programme. 88p.

Waugh, N. 2011. Farmer adaptation to change with the threat of regulation - the carrot or the stick. New Zealand Nuffield Farming Scholars Association Scholarship Report. 54p. 